


\section{DISCLAIMER}

This report was prepared as an account of work sponsored by an agency of the United States Government. Neither the United States Government nor any agency Thereof, nor any of their employees, makes any warranty, express or implied, or assumes any legal liability or responsibility for the accuracy, completeness, or usefulness of any information, apparatus, product, or process disclosed, or represents that its use would not infringe privately owned rights. Reference herein to any specific commercial product, process, or service by trade name, trademark, manufacturer, or otherwise does not necessarily constitute or imply its endorsement, recommendation, or favoring by the United States Government or any agency thereof. The views and opinions of authors expressed herein do not necessarily state or reflect those of the United States Government or any agency thereof. 


\section{DISCLAIMER}

Portions of this document may be illegible in electronic image products. Images are produced from the best available original document. 
This report was prepared as an account of work sponsored by an agency of the United States Government. Neither the United States Government nor any agency thereof, nor any of their employees, makes any warranty, express or implied, or assumes any legal liability or responsibility for the accuracy, completeness, or usefulness of any information, apparatus, product, or process disclosed, or represents that its use would not infringe privately owned rights. Reference herein to any specific commercial product, process, or service by trade name, trademark, manufacturer, or otherwise, does not necessarily constitute or imply its endorsement, recommendation, or favoring by the United States Government or any agency thereof. The views and opinions of authors expressed herein do not necessarily state or reflect those of the United States Government or any agency thereof.

\author{
Frinted in the United States of America \\ Available from \\ National Technical Information Service \\ U.S. Department of Commerce \\ 5285 Port Royal Road \\ Springfield, Virginia 22161
}

NTIS Price Codes: Printed Copy A02; Microfiche A01 
GA-A16108 SUMMARY UC-77

\title{
1170-MW(t) HTGR-PS/C PLANT APPLICATION STUDY REPORT: SRC-II PROCESS APPLICATION
}

\author{
by \\ R. RAO and A. T. McMAIN, JR.

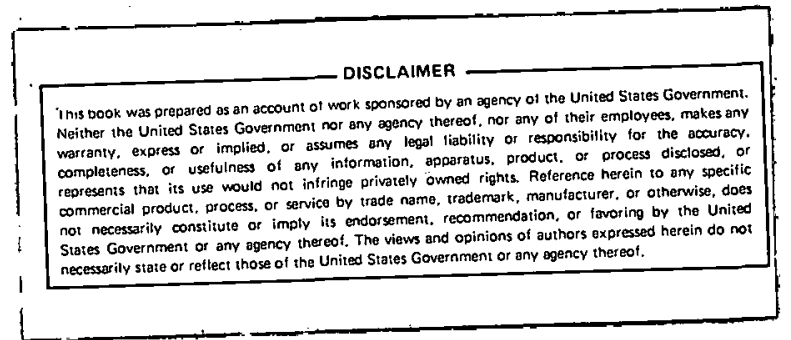 \\ Prepared under \\ Contract DE-AT03-76SF70046 \\ for the San Francisco Operations Office \\ Department of Energy
}

\author{
GENERAL ATOMIC PROJECT 6600 \\ DATE PUBLISHED: MAY 1981
}




\section{INTRODUCTION}

The solvent refined coal (SRC-II) process is an advanced process being developed by Gulf Mineral Resources Ltd. (a Gulf Oil Corporation subsidiary) to produce a clean, non-polluting liquid fuel from high-sulfur bituminous coals. The SRC-II commercial plant will process about 24,300 tonnes $(26,800$ tons) of feed coal per stream day, producing primarily fuel oil plus secondary fuel gases. This summary report describes the integration of a hightemperature gas-cooled reactor operating in a process steam/cogeneration mode (HTGR-PS/C) to provide the energy requirements for the SRC-II process.

The HTGR-PS/C plant was developed by General Atomic Company (GA) specifically for industries which require energy in the form of both steam and electricity. General Atomic has developed an 1170-MW( $t$ ) HTGR-PS/C design which is particularly well suited to industrial applications and is expected to have excellent cost benefits over other sources of energy. Because the HTGR produces high-temperature, high-pressure steam at conditions identical to those from fossil-fired boilers, there can be fairly direct substitution for existing large oil-or gas-fired industrial boilers and maximum flexibility in establishing cogeneration heat cycles to produce steam at conditions required for process use.

\section{APPLICATION REQUIREMENTS}

The SRC-II process flow diagram is shown in Fig. 1 and gives the steam conditions at various stages of the process where the HTGR-PS/C steam has been substituted for steam and direct-fired duties. The base case design included process steam being generated by direct gas-fired boilers and 


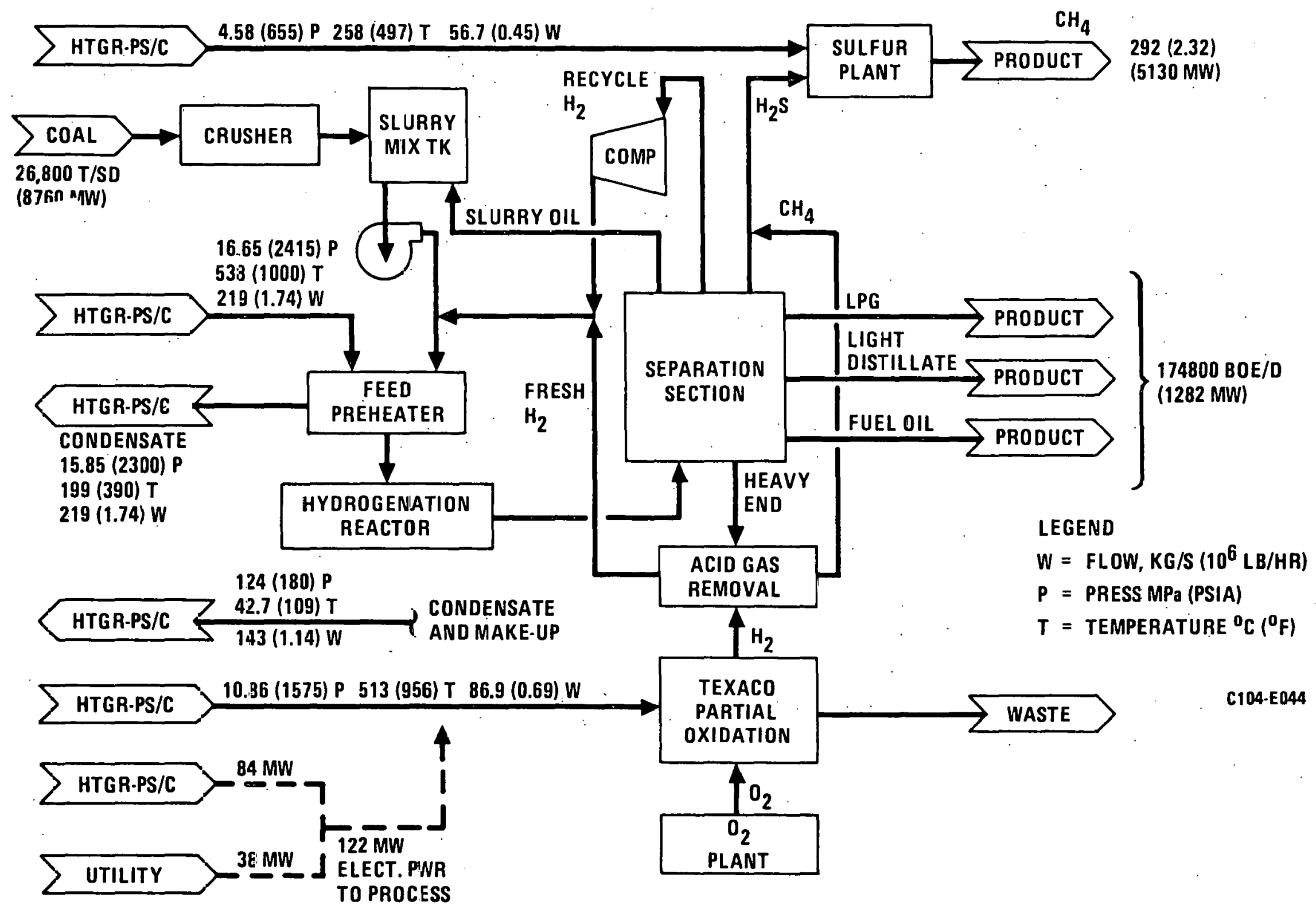

Fig. 1. Process flow diagram for 24,300 tonne (26,800 ton) per stream day SRC-II coal liquefaction application using an 1170-MW(t) HTGR-PS/C 
process heating by direct gas firing. The fuels utilized are hydrocarbonrich gas, Co-rich gas, and purified syngas (i.e., no feed coal is used for fuel). Table 1 presents the energy requirements; both thermal and electric, for an expanded SRC-II plant that processes about 24,300 tonnes $(26,800$ tons) of feed coal per stream day. Table 1 also gives the approximate quantities of gaseous fuels required for the SRC-II process. A review of Table 1 shows that a single HTGR-PS/C unit can supply these thermal requirements principally by substituting for the fuel gases previously employed. The displaced gases may be marketed or alternatively used.

All system thermal energy requirements in the form of process steam generation, steam superheating, and slurry heating are provided by the HTGRPS/C plant with its high-pressure [16.65 MPa (2415 psia)], high-temperature $\left[538^{\circ} \mathrm{C}\left(1000^{\circ} \mathrm{F}\right]\right.$ steam supply. The $1170-\mathrm{MW}(\mathrm{t})$ HTGR does not generate all the required electrical energy, and a deficit of about 38 MW electric power results.

PLANT DESIGN

The SRC-II heat loads and mechanical/electrical power loads are shown in Table 1. The 10.45-MPa (1515-psia) steam is supplied by throttiing the main steam from $16.65 \mathrm{MPa}$ (2415 psia). After throttling, the steam temperature is $513^{\circ} \mathrm{C}\left(956^{\circ} \mathrm{F}\right)$. The required $4.58-\mathrm{MPa}(665-\mathrm{psia})$ saturated steam is supplied from the high-pressure turbine exhaust, which is desuperheated using condensale recurn. The remaining four heat requirements are supplied by main steam through separate heat exchangers as shown in Fig. 2. The high-pressure condensate from these heaters, at $15.86 \mathrm{MPa}$ ( $2300 \mathrm{psia}$ ) and $199^{\circ} \mathrm{C}\left(390^{\circ} \mathrm{F}\right)$, is mixed with the other feedwater between the boiler feed pump and the top feedwater heater. The HTGR-PS/C plant cycle diagram for this service is shown in Fig. 3 .

All the SRC-II plant steam and heat requirements are satisfied either directly or through the heat exchangers. The excess steam supplies a 
TABLE 1

DATA BASE FOR SRC-II PROCESS ENERGY REQUIREMENTS FOR 24,300 TONNES (26,800 TONS) OF PEED COAL PER STREAM DAY

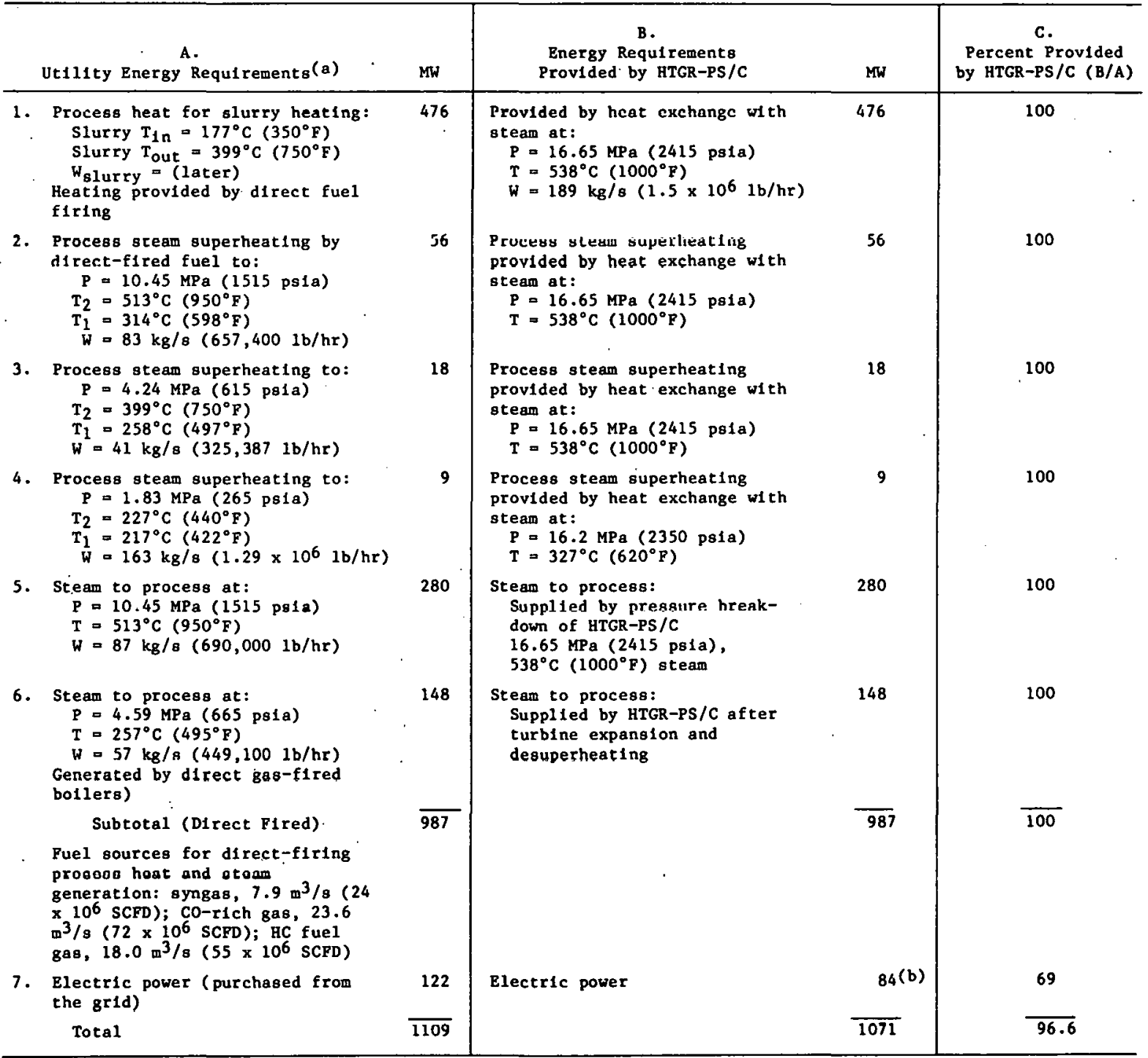

${ }^{(a)} P$ = pressure, $T$ - temperature, $W$ - flow.

(b) $A$ total of $115 \mathrm{MW}(\mathrm{e})$ is cogenerated by the HTGR-PS/C. Of th1s, $84 \mathrm{MW}(\mathrm{e})$ 1s ava1lable after HTGR-PS/C auxiliary requirements. 


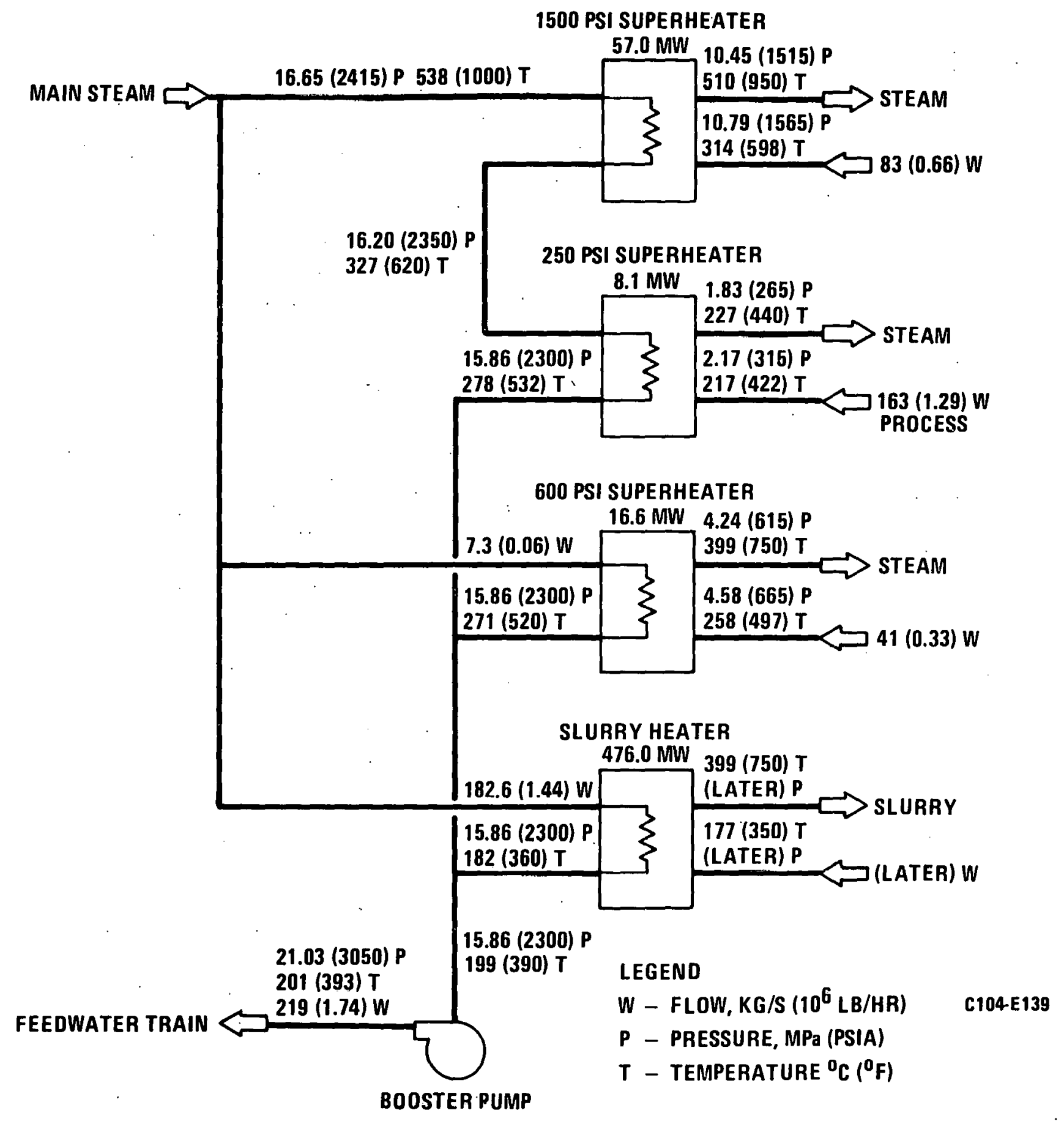

Fig. 2. Interfacing arrangement: HTGR-PS/C to SRC-II process 


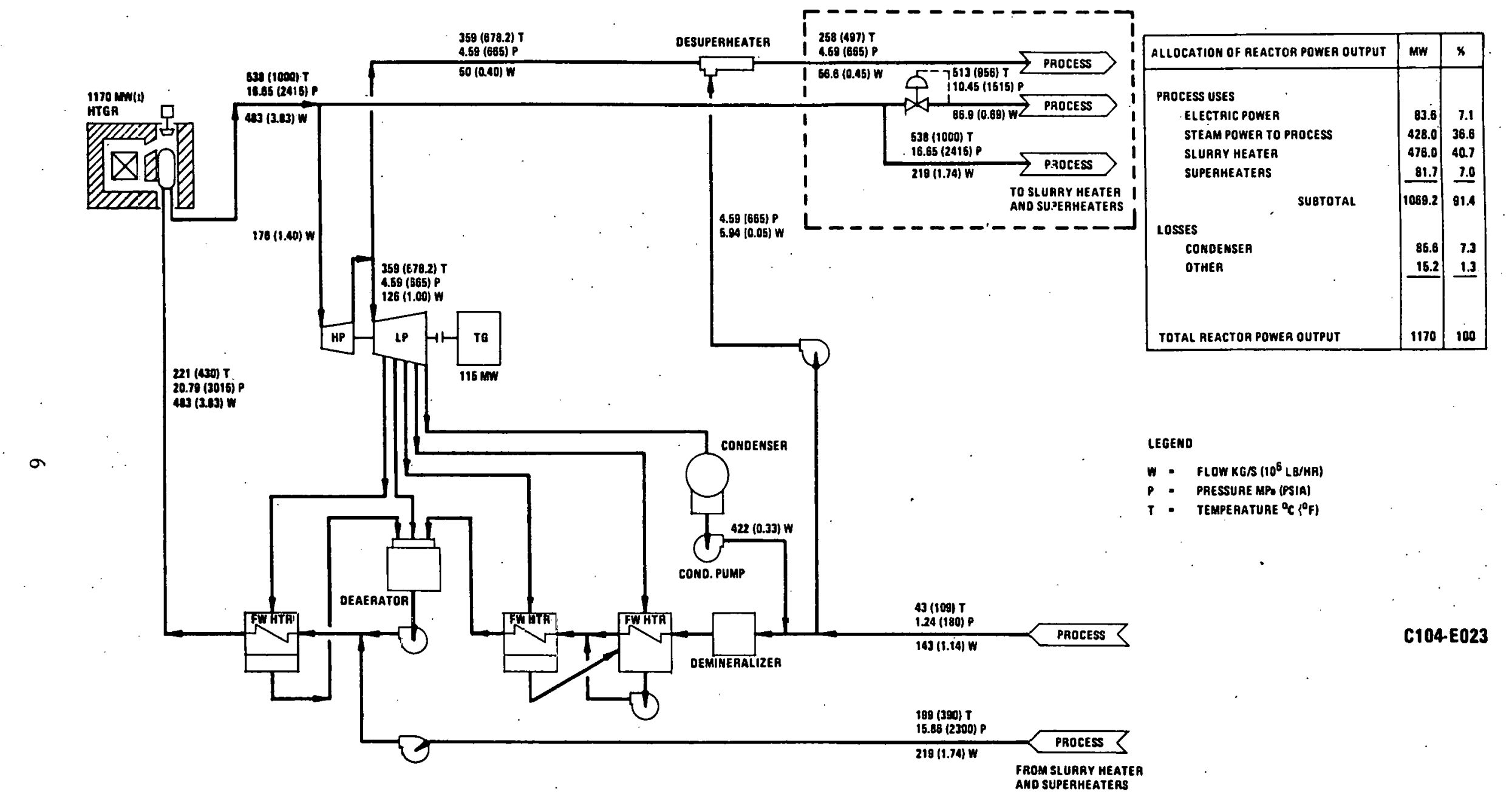

Fig. 3. Heat cycle for 24,300 tonne $(26,800$ ton) per stream day SRC-II coal liquefaction plant using an 1170-MW(t) HTGR-PS/C 
condensing steam turbine-generator that produces $115 \mathrm{MW}$ and heats all the feedwater for return to the steam generators. The net electrical output of the plant is $83.50 \mathrm{MW}$.

For completeness, studies were also conducted on utilizing steamto-steam rebollers to isolate the primary steam from process steam. The cycle developed for this case supplies slightly less process heat, but somewhat more electric power, than the cycle without reboilers.

ECONOMIC ASSESSMENT

The revenue requirement method was selected as the economic tool for evaluating alternative application projects, since it is appropriate for evaluation of long-lived coal and nuclear cogeneration power plants. The revenue requirement method determines the revenue needed by the firm as compensation for all expenditures, fixed and variable. Hence, the revenue requirements of the user are the cost to the consumer of the process steam cogenerated.

Table 2 shows the economic evaluation results for the 1170-MW(t) HTGRPS/C plant and for comparable coal-fired PS/C plants. A clear advantage of the HTGR-PS/C over a coal-fired plant is seen for this SRC-II process application. The analysis is based on economic assumptions used for evaluation of utility cogeneration projects in work being performed for the DOE. Such work is being carried out by General Atomic in coordination with Gas Cooled Reactor Associates (GCRA). Table 3 gives the principal assumptions of the economic analysis, a key one being the $18 \%$ fixed charge rate for capital use/recovery. Such a rate may be higher when industrial ownership ground rules are applied. Therefore, the economics should be determined using the economic ground rules specific to the SRC-II application. Industrial user input is being developed regarding possible alternate economic ground rules that should be utilized. 
TABLE 2

ECONOMIC ANALYSIS OF HTGR-PS/C AND COAL-FIRED PS/C PLANTS FOR SRC-II PROCESS APPLICATION

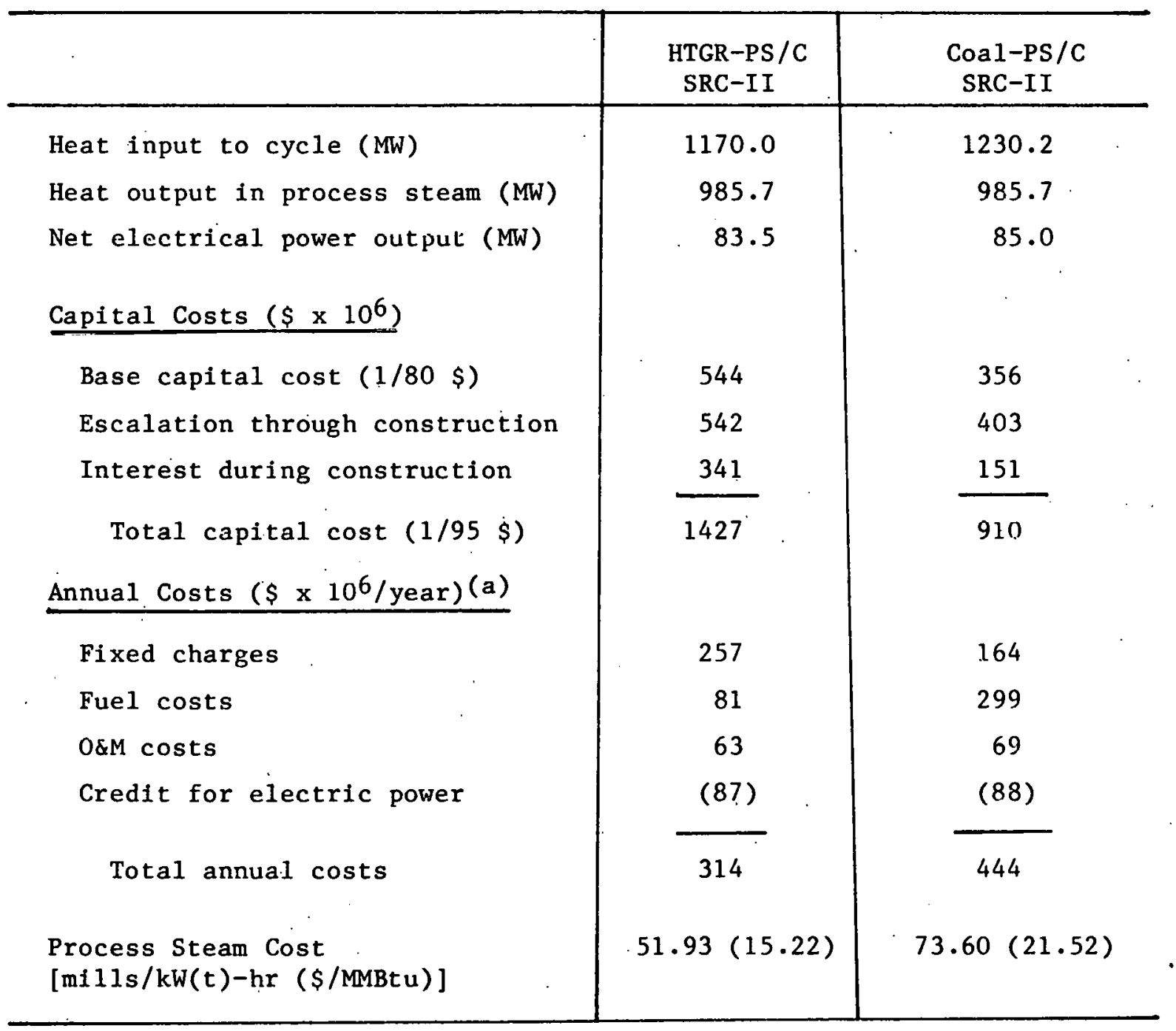

(a) $1 / 95$ \$ levelized over a 30 -year period. 
TABLE 3

KEY ECONOMIC ASSUMPTIONS FOR HTGR-PS/C SRC-II APPLICATIONS

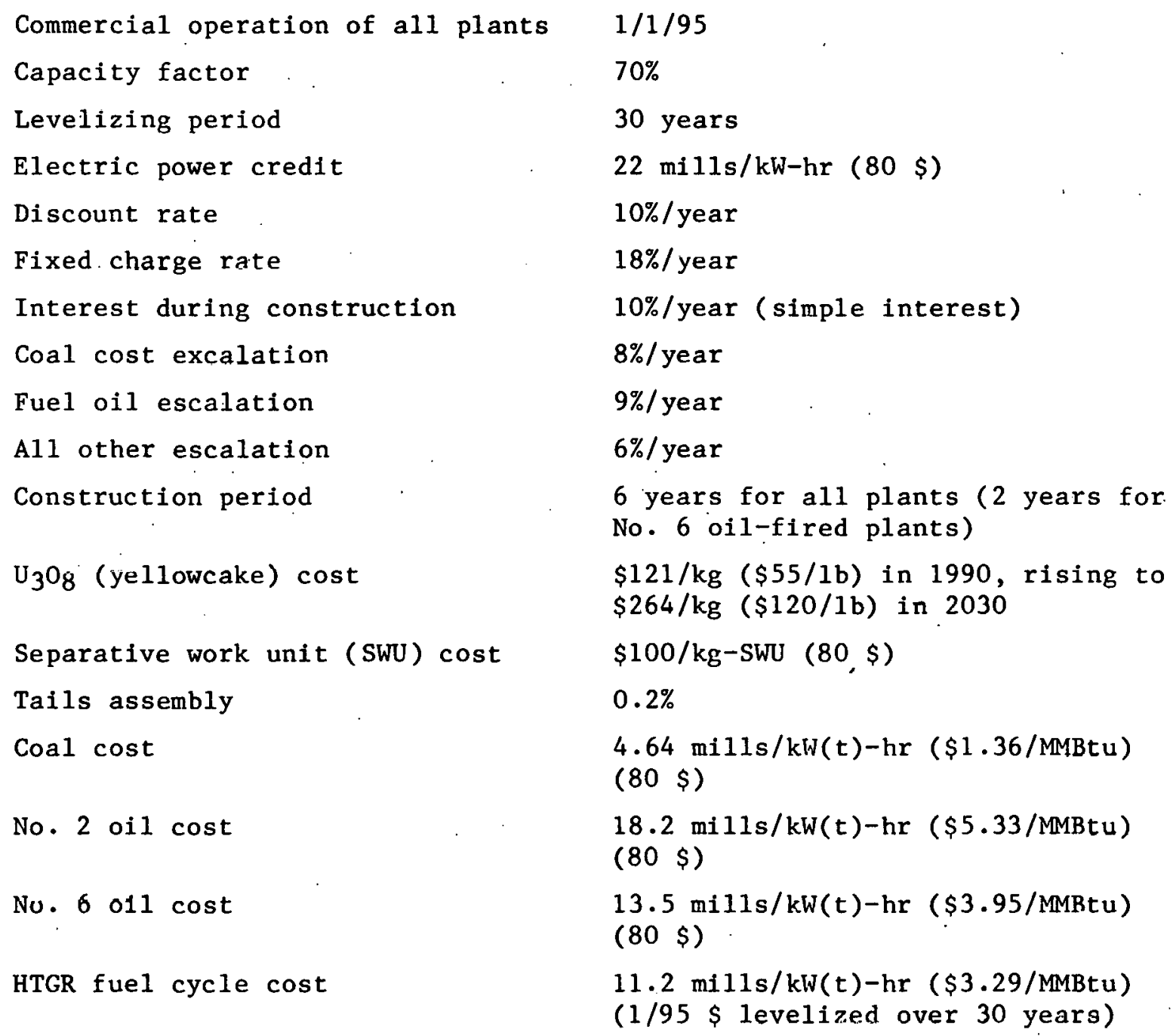


Ultimately, the method of economic analysis will be determined by the nuclear cogeneration plant ownership arrangement. Three ownership possibi1ities that should be considered are (1) industrial ownership with connection to the utility grid for backup electric power and sale of excess power Iper recent Federal Energy Regulatory Commission (FERC) rulings regarding a: more favorable arrangement for industry], (2) utility ownership with both steam and cogenerated electric power sold to nearby industry, and (3) consortia ownership and sale of energy to industry and local utilities.

The substantial advantage of the HTGR-PS/C over coal, indicated in Table 2 is primarily due to the much lower fuel cost of the nuclear plant despite its higher capital cost. This advantage is enhanced by long leve1ization periods, which in effect provide a smaller fixed charge rate for the use/recovery of capital. The fixed charge rate can also be reduced if shorter periods for depreclating the plant are permitted for tax purposes, which may be quite possible in view of the national goal to reduce imported 011/gas use.

The technical risk for the HTGR-PS/C for the subject application is considered small. The timescale for development is satisfactory, and the licensing risk should be relatively modest since the plant is likely to be relatively remotely located and since the licensing risk is only an increment upon already extensive licensing requirements for the process plant itself. The HTGR-PS/C is particularly suited for this application, whirh requires significant quantities of steam at conditions of $10.45 \mathrm{MPa}$ ( 1500 psig) and $510^{\circ} \mathrm{C}\left(950^{\circ} \mathrm{F}\right)$ that cannot be obtained from an LWR without fossil superheating . 